\title{
KOMPETENSI PROFESIONAL GURU, MOTIVASI BELAJAR, DAN GAYA BELAJAR BERPENGARUH TERHADAP PEMAHAMAN EKONOMI SISWA KELAS XI IPS DI SMA NEGERI 1 GONDANG, NGANJUK
}

\author{
Dwi Nila Andriani, Universitas Negeri Surabaya \\ dwinilaa@yahoo.com
}

\begin{abstract}
ABSTRAK
Penelitian ini bertujuan untuk menganalisis pengaruh Kompetensi Profesional, Motivasi, dan Gaya Belajar Siswa terhadap Pemahaman Ekonomi Kelas XI IPS di SMA Negeri 1 Gondang, Nganjuk. Pendekatan yang digunakan dalam penelitian ini adalah pendekatan kuantitatif. Populasi dalam penelitian ini adalah siswa kelas XI IPS di SMA Negeri 1 Gondang sebanyak 112 siswa. Dalam penelitian ini teknik sampling yang digunakan adalah Simple Random Sampling, dengan jumlah sampel sebanyak 88 responden. Hasil penelitian menunjukkan bahwa Ada pengaruh signifikan kompetensi profesional guru, motivasi belajar dan gaya belajar secara bersama-sama terhadap pemahaman ekonomi yaitu sebesar 77,3\%.

Kata Kunci: Kompetensi Profesional Guru, Motivasi Belajar, Gaya Belajar, dan Pemahaman Ekonomi

ABSTRACT

The aims of this research are for Analyzing the influence of professional teacher competence, learning motivation, and learning styles of students for economic understanding of eleventh grades student of SMA Negeri 1 Gondang, Nganjuk. In this research, writer uses quantitative methods as a research methodology. Population in this research are eleventh grades students in SMA Negeri 1 Gondang who are 112 students. Writer uses Simple Random Sampling as a Research technique which consists of 88 samples. Result of this research shows There is 77, 3\% significance between professional teacher competence, students' learning motivation, students' learning styles and economic understanding of students.
\end{abstract}

Keywords: Professional teacher competence, Learning motivation, learning styles and economic understanding.

\section{PENDAHULUAN}

Proses pendidikan merupakan suatu sistem yang terdiri dari input, proses dan output. Input disini merupakan peserta didik yang akan melaksanakan aktivitas belajar, proses merupakan kegiatan selama belajar mengajar sedangkan output merupakan hasil dari proses pembelajaran yang dilaksanakan. Dari proses pembelajaran tersebut diharapkan dapat menghasilkan sumber daya manusia yang berkualitas dan berdaya saing tinggi untuk menghadapi persaingan di era sekarang ini. Salah satu cara menciptakan sumber daya yang berkualitas adalah melalui pendidikan. Pendidikan adalah usaha sadar dan sistematis untuk mencapai taraf 
hidup atau kemajuan yang lebih baik. Pendidikan dapat diterapkan melalui suatu proses pembelajaran yang terstruktur dan terarah. Belajar merupakan suatu proses usaha yang dilakukan seseorang untuk memperoleh suatu perubahan tingkah laku yang baru secara keseluruhan sebagai hasil pengalamannya sendiri dalam interaksi dengan lingkungannya, yang secara ideal harus mengacu pada tiga aspek yaitu kognitif/perubahan pengetahuan, psikomotorik/perubahan ketrampilan dan afektif/perubahan nilai dan sikap (Hamalik, 2004).

Menurut Undang-Undang Republik Indonesia Nomor 20 tahun 2003 pasal 3 menyatakan bahwa pendidikan nasional berfungsi mengembangkan kemampuan dan membentuk watak serta peradaban bangsa yang bermartabat dalam rangka mencerdaskan kehidupan bangsa, selain itu mempunyai tujuan untuk mengembangkan potensi peserta didik agar menjadi manusia yang beriman dan bertakwa kepada Tuhan Yang Maha Esa, berakhlak mulia, sehat, berilmu, cakap, kreatif, mandiri, dan menjadi warga negara yang demokratis serta bertanggung jawab. Guru merupakan komponen paling menentukan dalam sistem pendidikan secara keseluruhan yang harus mendapat perhatian utama, karena guru merupakan sosok yang senantiasa menjadi sorotan ketika berbicara masalah pendidikan.

Dan guru juga memegang peranan utama dalam pembangunan pendidikan, khusunya pendidikan formal yang ada di sekolah. Untuk menjadi guru yang profesional harus memiliki beberapa kompetensi. Dalam Undang-Undang No. 14 Tahun 2005 tentang guru dan dosen disebutkan bahwa kompetensi guru meliputi kompetensi pedagogik, kompetensi kepribadian, kompetensi sosial, dan kompetensi profesional. Tercapainya tujuan pendidikan nasional dapat dilihat dari tingkat pemahaman siswa tentang materi yang telah disampaikan. Tingkat pemahaman ekonomi kurang memuaskan apabila peserta didik belum mampu memenuhi target dalam kriteria yang telah ditentukan, yaitu KKM. Menurut Gintings (2010) mengemukakan bahwa motivasi berperan penting dalam pembelajaran karena dengan adanya motivasi siswa tidak hanya akan belajar giat tetapi juga menikmatinya. Tanpa motivasi, siswa tidak akan tertarik dan serius dalam mengikuti pembelajaran.

Faktor lain yang berpengaruh terhadap pemahaman ekonomi yaitu gaya belajar siswa. Gaya belajar ini merupakan cara dan kebiasaan siswa dalam mempelajari sesuatu. Kadangkala siswa belum mengetahui dan memahami gaya belajarnya sendiri, sebagian besar masih beranggapan bahwa belajar itu merupakan suatu tuntutan bukan kebutuhan. Akibatnya mereka tidak memperdulikan bagaimana cara belajar yang menyenangkan untuk dirinya, padahal dengan memahami gaya belajar siswa akan lebih optimal dalam belajar. Dalam pembelajaran ekonomi secara umum siswa SMA kelas XI IPS lebih dominan menggunakan gaya belajar visual dan auditorial. Hal ini bisa dilihat dari kegiatan pembelajaran di kelas, siswa memahami materi yang diajarkan dengan cara melihat dan mendengar guru menjelaskan.

Pada ulangan harian yang pertama mata pelajaran ekonomi sebesar 68 siswa mendapatkan nilai dibawah KKM atau sebesar $61 \%$ mendapatkan nilai di bawah KKM (Kriteria Ketuntasan Minimal), dan sisanya sebesar 39\% mendapatkan nilai di atas 77 (di atas KKM). Kondisi tersebut menunjukkan bahwa pemahaman ekonomi di kelas XI IPS SMA Negeri 1 Gondang masih rendah. Menurut Sardiman (2011) faktor-faktor yang mempengaruhi prestasi belajar meliputi faktor internal dan eksternal. Guru merupakan salah satu faktor penentu berhasil 
tidaknya suatu pembelajaran. Keberhasilan penyelenggaraan pembelajaran sangat ditentukan oleh sejauh mana kesiapan guru dalam mempersiapkan peserta didiknya melalui kegiatan pembelajaran. Apabila guru memiliki kesiapan yang kurang, guru tersebut tidak dapat memberikan performa yang optimal, dan cenderung kurang bagus sehingga persepsi siswa terhadap guru tersebut biasanya menjadi negatif dan memandang rendah. Oleh karena itu kompetensi profesional guru dinilai sangat berpengaruh terhadap pemahaman dalam pembelajaran ekonomi.

Motivasi siswa kelas XI IPS menunjukkan bahwa motivasi yang dimiliki masih kurang. Hal ini dapat dilihat dari siswa terlambat datang atau masuk kelas, kurang semangat saat mengikuti pembelajaran di kelas, kurang memiliki sikap kemandirian, dan masih adanya siswa yang membolos saat kegiatan belajar mengajar berlangsung. Deporter dan Hernacki (2010) menyatakan bahwa gaya belajar seseorang adalah kombinasi dari bagaimana ia menyerap, dan kemudian mengatur serta mengolah informasi. Kemampuan menyerap informasi setiap siswa cenderung berbeda berdasarkan modalitas belajarnya. . Gaya belajar yang berbeda pada masing-masing siswa tentu mempengaruhi penyerapan pelajaran demikian pula halnya dengan strategi pembelajaran yang diterapkan guru. Siswa SMA Negeri 1 Gondang ini mempunyai jumlah siswa yang banyak dengan karakter yang berbeda-beda sehingga mereka mempunyai gaya belajar yang berbeda pula. Kompetensi profesional guru yang baik, motivasi belajar siswa tinggi, dan gaya belajar dari siswa yang sesuai dapat membuat peserta didik memahami materi yang telah disampaikan sehingga dapat diaplikasikan ke kehidupan mereka, khusunya pada pemahaman ekonomi.

Sesuai dengan penelitian yang dilakukan oleh Sulistyowati (2012), menunjukkan bahwa motivsi belajar dan kompetensi profesionalisme guru berpengaruh secara langsung sebesar $47,7 \%$ terhadap prestasi belajar mata pelajaran ekonomi. Penelitian lain yang mendukung yaitu oleh Iriani (2013) tentang identifikasi gaya belajar dan pengaruhnya terhadap hasil belajar siswa, hasil penelitiannya menunjukkan bahwa terdapat pengaruh yang signifikan gaya belajar terhadap hasil belajar, besar pengaruh dari gaya belajar terhadap hasil belajar sebesar $18,85 \%$.

Penelitian yang akan dilakukan ini adalah menguji kembali serta memberikan penguatan dan lebih melengkapi penelitian sebelumnya, sehingga penelitian ini digolongkan dalam penelitian justifikasi. Melalui replikasi terhadap penelitian terdahulu, penelitian ini menguji kembali apakah faktor-faktor yang mempengaruhi hasil belajar siswa sebagaimana diungkapkan oleh beberapa peneliti terdahulu signifikan untuk siswa kelas XI IPS SMA Negeri 1 Gondang (tempat dilaksanakan penelitian). Faktor yang dikaji adalah kompetensi guru, motivasi belajar dan gaya belajar siswa terhadap pemahaman ekonomi. Tujuan penelitian ini adalah sebagai berikut : (1) Menganalisis pengaruh Kompetensi Profesional Guru terhadap Pemahaman Ekonomi Kelas XI IPS di SMA Negeri 1 Gondang, Nganjuk. (2) Menganalisis Pengaruh Motivasi Belajar terhadap Pemahaman Ekonomi Kelas XI IPS di SMA Negeri 1 Gondang, Nganjuk. (3) Menganalisis Pengaruh Gaya Belajar Siswa terhadap Pemahaman Ekonomi Kelas XI IPS di SMA Negeri 1 Gondang, Nganjuk. (4) Menganalisis pengaruh kompetensi profesional guru, motivasi belajar siswa, dan gaya belajar siswa 
terhadap pemahaman ekonomi Kelas XI IPS di SMA Negeri 1 Gondang, Nganjuk.

Menurut Majid (2011), mendefinisikan bahwa, "Standar kompetensi guru adalah suatu ukuran yang ditetapkan atau dipersyaratkan dalam bentuk penguasaan pengetahuan dan berperilku layaknya seorang guru untuk menduduki jabatan fungsional sesuai bidang tugas, kualifikasi, dan jenjang pendidikan". Pendapat lain yaitu dari Sagala (2004), "mengatakan bahwa guru secara sederhana dapat diartikan sebagai orang yang memberikan ilmu pengetahuan kepada anak didik". Karena tugasnya itulah, guru dapat menambah kewibawaannya dan keberadaan guru sangat diperlukan masyarakat, mereka tidak meragukan lagi akan pentingya guru bagi anak didik. Sedangkan Usman (2011) menyatakan bahwasanya guru yang mempunyai kompetensi profesional adalah guru yang mempunyai ciri-ciri seperti berikut : menguasai landasan pendidikan, menguasai bahan pengajaran, menyusun program pengajaran, melaksanakan program pembelajaran yang telah disusun, dan menilai hasil program pelajaran yang dilaksanakan. Guru yang kompeten akan lebih mampu menciptakan lingkungan belajar yang efektif, menyenangkan, dan lebih mampu mengelola kelasnya, sehingga proses belajar mengajar menjadi optimal.

Sardiman (2011) mendefinisikan motivasi sebagai keseluruhan daya penggerak di dalam diri siswa yang menimbulkan kegiatan belajar, yang menjamin kelangsungan dari kegiatan belajar dan yang memberikan arah pada kegiatan belajar. Menurut Suprijono (2011) Motivasi belajar adalah proses yang memberi semangat belajar, arah, dan kegigihan perilaku. Artinya, perilaku yang termotivasi adalah perilaku yang penuh energi, terarah dan bertahan. Jadi peran motivasi bagi siswa dalam belajar sangat penting. Dengan adanya motivasi akan meningkatkan, memperkuat dan mengarahkan proses belajarnya, sehingga akan diperoleh keefektifan dalam belajar.

Nasution (2008) mengemukakan gaya belajar atau learning style adalah cara yang konsisten yang dilakukan oleh seorang siswa dalam menangkap stimulus atau informasi, cara mengingat, berpikir, dan memecahkan soal. Deporter dan Hernacki (2010) mengemukakan bahwa gaya belajar adalah kombinasi bagaimana anda menyerap, dan kemudian mengatur serta mengelola informasi. gaya belajar adalah gaya konsisten yang ditunjukan individu untuk menyerap informasi, mengatur, mengelola informasi tersebut dengan mudah dalam proses penerimaan, berfikir, mengingat, dan pemecahan masalah dalam menghadapi proses belajar mengajar agar tercapai hasil maksimal sesuai dengan kemampuan, kepribadian, dan sikapnya. Menurut Trianto (2010), proses belajar terjadi melalui banyak cara baik disengaja maupun tidak disengaja dan berlangsung sepanjang waktu dan menuju pada perubahan pada diri pembelajar.

Purwanto (2000) mengemukakan bahwa kemampuan pemahaman (comprehension) adalah tingkat kemampuan yang menurut peserta didik mampu memahami arti atau konsep, situasi serta fakta yang diketahui. Dalam hal ini peserta didik tidak hanya hafal, tetapi mengerti atau paham terhadap konsep atau fakta yang ditanyakan. Menurut Bloom (dalam Anderson, 2001) pemahaman adalah kemampuan seseorang untuk mengerti atau memahami sesuatu setelah sesuatu itu diketahui dan diingat. Jadi pemahaman materi pelajaran ekonomi yang dimaksud dalam penelitian ini adalah kemampuan siswa untuk memahami atau mengerti materi pelajaran ekonomi yang diperoleh selama kegiatan belajar 
mengajar di sekolah dengan caranya sendiri tidak hanya hafal secara verbalitas, tetapi mengerti atau paham terhadap konsep atau fakta yang ditanyakan. ditunjukkan dengan hasil yang ingin dicapai siswa yang dinilai melalui tes.

Penelitian oleh Hasrul (2009), pemahaman tentang gaya belajar. Hasil penelitiannya adalah efektifitas pembelajaran mengacu pada pencapaian tujuan untuk menetapkan metode dan teknikyang efektif dan efisien diperlukan pedoman yang bersumber dari berbagai faktor yaitu, tujuan pembelajaran, peserta didik, dan sarana atu prasarana yang mendukung. Lilik (2012), pengaruh gaya belajar motivasi, dan pemahaman akuntansi terhadap indeks prestasi mahasiswa akuntansi. Hasil penelitian ini menunjukan bahwa gaya belajar tidak mempunyai pengaruh yang signifikan terhadap indeks prestasi, motivasi dalam penelitian ini tidak mempunyai pengaruh yang signifikan terhadap indeks prestasi, dan pemahaman akuntansi tidak mempunyai pengaruh yang signifikan terhadap indeks prestasi. jadi gaya belajar, motivasi dan pemahaman akuntansi tidak berpengaruh secara signifikan terhadap indeks prestasi. Kulshrestha (2013), Teachers Training And Professional Competencies. Penelitian ini membahaskompetensi profesional guru. Kompetensi tersebut berpengaruh langsung terhadap perkembangan pendidikan, terutama pada peserta didik dan pemahaman ekonomi peserta didik.

\section{METODE PENELITIAN}

Jenis penelitian yang digunakan adalah penelitian tingkat eksplanasi. Menurut David Kline (dalam Sugiyono, 2007) tingkat eksplanasi merupakan tingkat penjelasan. Jadi penelitian ini adalah penelitian yang menjelaskan variabel-variabel yang diteliti serta pengaruh antara satu variabel dengan variabel yang lain. Pendekatan yang digunakan dalam penelitian ini adalah pendekatan kuantitatif. Sugiyono (2010) pendekatan kuantitatif dapat diartikan sebagai metode yang berdasarkan pada filsafat positivisme, digunakan untuk meneliti populasi atau sampel tertentu, teknik pengambilan sampel pada umumnya dilakukan secara random dan pengumpulan data menggunakan instrumen penelitian, analisis bersifat kuantitatif/statistik dengan tujuan untuk menguji hipotesis yang telah ditetapkan.

\section{Tabel 1}

Indikator Variabel Penelitian

\begin{tabular}{|l|l|l|}
\hline \multicolumn{1}{|c|}{ Variabel } & \multicolumn{1}{|c|}{ Indikator } & \multicolumn{1}{c|}{ Sumber } \\
\hline Kompetensi & 1) Menguasai landasan kependidikan, 2) & Usman (2011), \\
Profesional Guru & $\begin{array}{l}\text { Menguasai bahan pengajaran, 3) Menyusun } \\
\text { program pengajaran, 4) Melaksanakan } \\
\text { program pengajaran, 5) Menilai hasil dan } \\
\text { proses belajar mengajar yang telah } \\
\text { dilaksanakan. }\end{array}$ & tahun 2005 \\
\hline Motivasi Belajar & $\begin{array}{l}\text { 1) Tekun menghadapi tugas, 2) Tidak mudah } \\
\text { melepaskan hal yang diyakini, 3) Lebih } \\
\text { senang bekerja mandiri, 4) Cepat bosan pada } \\
\text { tugas-tugas rutin, 5) Dapat mempertahankan } \\
\text { pendapat, 6) Ulet menghadapi kesulitan, 7) } \\
\text { Senang mencari dan memecahkan soal-soal. }\end{array}$ & Sardiman (2011) \\
\hline
\end{tabular}




\begin{tabular}{|l|l|l|}
\hline Gaya Belajar & $\begin{array}{l}\text { 1) Gaya belajar visual, 2) Gaya belajar } \\
\text { auditorial }\end{array}$ & $\begin{array}{l}\text { Depporter dan } \\
\text { Hernacki (2010) }\end{array}$ \\
\hline $\begin{array}{l}\text { Pemahaman } \\
\text { Ekonomi }\end{array}$ & $\begin{array}{l}\text { Nilai ulangan harian selama kelas XI } \\
\text { (semester ganjil dan genap) }\end{array}$ & Purwanto (2000) \\
\hline
\end{tabular}

Kompetensi profesional guru merupakan kemampuan khusus yang dimiliki oleh seorang tenaga pendidik untuk memberikan pengetahuan kepada peserta didik. Indikatornya adalah menguasai landasan kependidikan, menguasai bahan pengajaran, menyusun program pengajaran, melaksanakan program pengajaran, menilai hasil dan proses belajar mengajar yang telah dilaksanakan. Motivasi belajar siswa merupakan keseluruhan daya penggerak psikis dalam diri siswa yang menimbulkan kegiatan belajar dan memberikan arah pada kegiatan belajar, sehingga siswa tidak hanya belajar namun juga menghargai dan menikmati kegiatan belajarnya. Indikator dari motivasi adalah tekun menghadapi tugas, ulet menghadapi kesulitan, lebih senang bekerja mandiri, cepat bosan pada tugas-tugas rutin, dapat mempertahankan pendapatnya, tidak mudah melepaskan hal yang diyakini itu, senang memecahkan masalah soal-soal. Gaya belajar merupakan cara peserta didik dalam menerima materi pembelajaran, dimana ada tiga modalitas belajar yaitu, visual, auditorial dan kinestetik. Yang menjadi Indikator dalam penelitian ini adalah gaya belajar auditorial dan visual. Dan Pemahaman Ekonomi ialah kemampuan-kemampuan yang diperoleh siswa setelah ia terlibat dalam proses pembelajaran ekonomi di sekolah pada tahun ajaran 20013/2014.

Populasi menurut Sugiyono (2010) adalah wilayah generalisasi yang terdiri atas obyek atau subyek yang mempunyai kualitas dan karakteristik tertentu yang ditetapkan oleh peneliti untuk dipelajari dan kemudian ditarik kesimpulannya. Secara singkat dapat dikatakan bahwa populasi adalah semua anggota kelompok orang, kejadian atau obyek yang dirumuskan secara jelas. Populasi dalam penelitian ini adalah kelas XI IPS SMA Negeri 1 Gondang sebanyak 112 siswa. Sampel adalah bagian dari jumlah dan karakteristik yang dimiliki oleh populasi, sampel yang diambil dari populasi harus betul-betul representatif atau mewakili (Sugiyono, 2010). Dalam penelitian ini teknik sampling yang digunakan adalah Simple Random Sampling. Simple Random Sampling adalah Teknik pengambilan anggota sampel dari populasi dilakukan secara acak tanpa memperhatikan strata yang ada dalam populasi itu (Sugiyono, 2010). Dalam teknik simple random sampling setiap anggota dari populasi mempunyai kesempatan yang sama untuk dimasukkan ke dalam sampel. Cara yang digunakan dalam penelitian ini yaitu dengan menggunakan undian. Dalam penentuan besarnya sampel yaitu dengan menggunakan teknik proporsi, dengan jumlah sampel sebesar 88 responden.

Dalam penelitian ini menggunakan teknik atau metode pengambilan data yaitu kuesioner dan dokumentasi. Kuesioner merupakan teknik pengumpulan data yang dilakukan dengan cara memberi seperangkat pertanyaan atau pernyataan tertulis kepada responden untuk dijawabnya (Sugiyono, 2010). Kuesioner dalam penelitian ini digunakan untuk memperoleh data tentang variabel kompetensi profesional guru (XI), motivasi belajar (X2), dan gaya belajar (X3) pengaruhnya terhadap pemahaman ekonomi siswa kelas XI IPS. Variabel kompetensi profesional guru, motivasi belajar dan gaya belajar yang muncul dalam bentuk skor kemudian dianalisis. Angket diberikan kepada responden, yaitu siswa kelas XI IPS SMA N 1 Gondang, Nganjuk semester genap tahun ajaran 2013/2014. 
Metode dokumentasi yaitu mencari data mengenai hal-hal atau variabel yang berupa catatan , transkip, buku, surat kabar, majalah, prasasti, notulen rapat, agenda dan sebagainya (Sugiyono, 2010). Metode dokumentasi dalam penelitian ini dilakukan untuk mendapatkan data yang berupa dokumentasi, seperti pedoman akademik, susunan pejabat struktural lembaga pendidikan formal, khususnya SMA Negeri 1 Gondang. Dalam penelitian ini, informasi dan data tertulis yang diambil adalah nilai ulangan kelas XI IPS.

\section{HASIL PENELITIAN DAN PEMBAHASAN}

\section{Hasil Penelitian}

Analisis regresi linier berganda adalah hubungan secara linier antara variabel independen yaitu kompetensi profesional guru (X1), motivasi belajar (X2), dan gaya belajar (X3) dengan variabel pemahaman ekonomi (Y) sebagai variabel dependen. Analisis ini untuk mengetahui arah hubungan antara variabel independen dengan variabel dependen apakah masing-masing variabel independen berhubungan positif atau negatif dan untuk memprediksi nilai dari variabel dependen apabila nilai variabel independen mengalami kenaikan atau penurunan. Adapun hasil pengolahan data dengan metode regresi linier berganda adalah sebagai berikut $\mathrm{Y}=-24,285+0,192 \mathrm{X} 1+0,878 \mathrm{X} 2+0,248 \mathrm{X} 3$. Dari persamaan regresi di atas menjelaskan bahwa :

1. Konstanta (a) yang dihasil kan sebesar $-24,285$ hal ini menunjukkan bahwa besarnya pemahaman ekonomi siswa adalah -24,285 jika variabel kompetensi profesional guru, motivasi belajar, dan gaya belajar adalah nol atau konstan. Nilai konstanta yang negatif ini dapat berarti jika variabel kompetensi profesional guru, motivasi belajar dan gaya belajar tidak memberikan kontribusi, maka nilai rata-rata dari pemahaman dianggap nol. Jadi pemahaman ekonomi siswa apabila X1, X2 dan X3 konstan atau nol adalah rendah. Ketika belum ada pembelajaran ekonomi di kelas berarti pemahaman siswa akan ekonomi benar-benar rendah.

2. Koefisien regresi pada variabel kompetensi profesional guru adalah positif yaitu sebesar 0,192 artinya jika variabel kompetensi profesional guru (X1) naik satu satuan maka variabel pemahaman ekonomi (Y) akan naik sebesar 0,192 satuan dengan asumsi bahwa variabel yang lain (motivasi belajar dan gaya belajar) adalah konstan.

3. Koefisien regresi pada variabel motivasi belajar adalah positif yaitu sebesar 0,878 artinya jika variabel motivasi belajar (X2) naik satu satuan maka variabel pemahaman ekonomi (Y) akan naik sebesar 0,878 satuan dengan asumsi bahwa variabel yang lain (kompetensi profesional guru dan gaya belajar) adalah konstan.

4. Koefisien regresi pada variabel gaya belajar adalah positif yaitu sebesar 0,248 artinya jika variabel gaya belajar (X3) naik satu satuan maka variabel pemahaman ekonomi (Y) akan naik sebesar 0,248 satuan dengan asumsi bahwa variabel yang lain (kompetensi profesional guru dan motivasi belajar) adalah konstan.

Nilai t hitung pada variabel kompetensi profesional guru (X1) sebesar 2,316 dengan tingkat signifikansi kurang dari $5 \%$ yaitu 0,023 . Hal ini berarti bahwa kompetensi profesional guru (X1) secara parsial berpengaruh secara signifikan 
terhadap pamahaman ekonomi (Y). besarnya pengaruh kompetensi profesional guru(X1) terhadap pemahaman ekonomi (Y) adalah 1,44\%. Motivasi belajar (X2) sebesar 9,306 dengan tingkat signifikansi kurang dari 5\% yaitu 0,000 . Hal ini berarti bahwa motivasi belajar (X2) secara parsial berpengaruh secara signifikan terhadap pamahaman ekonomi (Y). besarnya pengaruh motivasi belajar (X2) terhadap pemahaman ekonomi (Y) adalah 23,42\%. Gaya belajar (X3) sebesar 3,894 dengan tingkat signifikansi kurang dari 5\% yaitu 0,000 . Hal ini berarti bahwa gaya belajar (X3)) secara parsial berpengaruh secara signifikan terhadap pamahaman ekonomi (Y). besarnya pengaruh gaya belajar (X3) terhadap pemahaman ekonomi (Y) adalah 4,08\%.

Nilai Fhitung yang dihasilkan adalah 95,377 dengan nilai signifikansi 0,000 kurang dari 0,05. Sehingga dapat disimpulkan bahwa kompetensi profesional guru, motivasi belajar dan gaya belajar secara simultan berpengaruh signifikan terhadap pemahaman ekonomi. Berarti $\mathrm{H}_{0}$ ditolak dan hipotesis alternatif diterima. Nilai R-Square yang dihasilkan sebesar 0,773 menunjukkan bahwa pemahaman ekonomi siswa dipengaruhi oleh kompetensi profesional guru, motivasi belajar, dan gaya belajar sebesar 77,3\% sedangkan $22,7 \%$ dipengaruhi oleh faktor-faktor lain yang tidak dijelaskan dalam penelitian ini.

\section{Pembahasan}

\section{Pengaruh Kompetensi Profesional Guru terhadap Pemahaman Ekonomi.}

Dalam penelitian ini diperoleh hasil bahwa Kompetensi Profesional Guru (X1) secara parsial berpengaruh signifikan terhadap pemahaman ekonomi (Y). Hal ini di dasarkan pada hasil uji t yaitu nilai t hitungnya sebesar 2,316 dan tingkat signifikansinya kurang dari $5 \%$ yaitu 0,023 . Hal ini menunjukkan bahwa semakin tinggi tingkat kompetensi profesional guru maka semakin tinggi pemahaman ekonomi siswa kelas XI IPS di SMA Negeri 1 Gondang, Nganjuk. Adapun pengaruh kompetensi profesional guru (X1) terhadap pemahaman ekonomi adalah $1,44 \%$.

Sesuai dengan Undang-Undang Republik Indonesia nomor 14 tahun 2005 menyatakan bahwa kompetensi profesional adalah kemampuan penguasaan materi pembelajaran secara luas dan mendalam yang memungkinkan membimbing siswa memenuhi standar kompetensi yang ditetapkan dalan standar keguruan. Kompetensi profesional guru yang di ukur dalam penelitian ini dengan indikator menguasai landasan pendidikan, menguasai bahan pengajaran, menyusun program pengajaran, melaksanakan program pembelajaran yang telah disusun, dan menilai hasil program pelajaran yang dilaksanakan.

Lebih lanjut Djamarah (2011) menjelaskan bahwa guru yang bermutu niscaya mampu melaksanakan pendidikan, pengajaran dan pelathihan yang efektif dan efisien. Hamalik (2001) mengatakan bahwa keberhasilan proses belajar mengajar tidak hanya ditentukan oleh sekolah, pola dan struktur serta isi kurikulumnya, akan tetapi ditentukan oleh kompetensi guru yang mengajar dan membimbing siswa.

Hasil tersebut selaras dengan hasil penelitian terdahulu yang beberapa diantaranya adalah penelitian dari Mustofa (2007) yang menyatakan bahwa upaya pengembangan profesionalisme guru di Indonesia itu penting, karena ini mrupakan salah satu cara meningkatkan kemampuan peserta didik dalam kegiatan pembelajaran. Hasil penelitian ini juga sesuai dengan penelitian 
sebelumnya yang digunakan sebagai rujukan oleh peneliti. Penelitian yang dilakukan oleh Joy Telu (2012) yang menyatakan bahwa kompetensi guru yang baik dapat menguntungkan dan berdampak positif bagi siswa, karena berhubungan dengan nilai akademik mereka dalam proses pembelajaran di kelas.

Penelitian ini juga sejalan dengan penelitian sebelumnya yang dilakukan oleh Sulistyowati, dkk (2012) menyebutkan bahwa ada pengaruh kompetensi profesional guru terhadap prestasi belajar. Penelitian lain dari Kulshrestha (2013) yang menyatakan bahwa pemberian latihan pada guru dan kompetensi profesional, dua hal tersebut berpengaruh langsung terhadap perkembangan pendidikan terutama perkembangan pada peserta didik di kelas.

Dapat dikatakan bahwa guru ekonomi yang mempunyai kompetensi profesional tinggi, akan menghasilkan siswa dengan pemahaman yang baik pula pada mata pelajaran ekonomi, dan guru ekonomi yang mempunyai kompetensi profesional yang rendah, akan menghasilkan siswa dengan pemahaman yang rendah pula pada pelajaran ekonomi. Kompetensi profesional guru berpengaruh signifikan terhadap pemahaman ekonomi siswa kelas XI IPS SMAN 1 Gondang, Nganjuk didukung oleh temuan pada variabel kompetensi profesional guru dalam penelitian ini lebih dominan didukung oleh indikator menguasai bahan pengajaran. Hal ini dapat ditunjukkan oleh responden bahwa guru ekonomi menjelaskan keterampilan dan pengetahuan seperti apa yang harus siswa kuasai setelah kegiatan belajar mengajar (tujuan dari pembelajaran). Jadi guru ekonomi sebelum menjelaskan materi pada siswa memberikan tujuan dari pembelajaran tersebut.

Sehingga dapat disimpulkan bahwa guru yang mempunyai kompetensi profesional baik bisa meningkatkan pemahaman ekonomi siswa. Hal ini sesuai dengan teori dan penelitian yang telah dilakukan sebelumnya yang menyebutkan bahwa semakin tinggi keprofesionalan guru, maka tingkat pemahaman yang diperoleh akan semakin meningkat/tinggi. Hasil temuan tersebut menunjukkan bahwa kompetensi profesional guru dalam kegiatan belajar di kelas memberikan sumbangan positif terhadap pemahaman ekonomi siswa.

\section{Pengaruh Motivasi Belajar terhadap Pemahaman Ekonomi Siswa Kelas XI IPS di SMA Negeri 1 Gondang, Nganjuk}

Dalam penelitian ini diperoleh hasil bahwa motivasi belajar (X2) secara parsial berpengaruh signifikan terhadap pemahaman ekonomi (Y). hal ini di dasarkan pada hasil uji t yaitu nilai t hitungnya sebesar 9,306 dan tingkat signifikansinya kurang dari $5 \%$ yaitu 0,000 . Hal ini menunjukkan bahwa semakin tinggi tingkat motivasi belajar maka semakin tinggi pemahaman ekonomi siswa kelas XI IPS SMA Negeri 1 Gondang, Nganjuk. Adapun pengaruh motivasi belajar (X2) terhadap pemahaman ekonomi adalah 23,42\%.

Hal ini sesuai dengan teori yang dikemukakan oleh Sardiman (2011) menyatakan bahwa motivasi dapat berfungsi sebagai pendorong usaha dan pencapaian prestasi. Dengan adanya usaha yang tekun dan terutama didasari adanya motivasi, maka sesorang yang belajar tentunya akan dapat melahirkan tingkat pemahaman yang baik. Intensitas motivasi seorang siswa akan sangat menentukan tingkat pemahaman mereka terhadap pelajaran tersebut.

Hal ini juga sejalan dengan penelitian sebelumnya yang digunakan sebagai rujukan oleh peneliti. Penelitian yang dilakukan oleh Ghamari, (2010) hasil penelitian menyebutkan bahwa Terdapat pengaruh yang posistif dan signifikan 
antara motivasi internal pada siswa dengan prestasi belajar siswa. Hubungan antara motivasi internal dan prestasi belajar ini berpengaruh sama baik pada siswa perempuan dan siswa laki-laki. Penelitian lain yang mendukung adalah penelitian dari Hamdu (2011) Hasil penelitian menunjukkan motivasi belajar siswa memiliki pengaruh yang signifikan, dengan demikian dapat disimpulkan bahwa terdapat pengaruh motivasi belajar terhadap prestasi belajar.

Penelitian lain yang mendukung adalah penelitian dari Rejeki (2011) hasil penelitian ini mengemukakan bahwa terdapat pengaruh langsung positif kondisi ekonomi keluarga terhadap hasil belajar, terdapat pengaruh langsung positif motivasi belajar terhadap hasil belajar. Penelitian lain oleh Nurtilawati dkk, berjudul pengaruh gaya belajar dan motivasi belajar terhadap hasil belajar siswa pada mata pelajaran ekonomi.

Penelitian lain yang mendukung penelitian ini yaitu oleh Nurtilawati dkk, yang menyatakan bahwa adanya pengaruh positif motivasi belajar terhadap hasil belajar siswa. Penelitian lain oleh Sulistyowati, dkk (2012) secara simultan ada pengaruh yang signifikan antara motivasi belajar dan kompetensi profesional guru terhadap prestasi belajar IPS. Andartari (2013) menyatakan bahwa motivasi beajar terhadap hasil belajar akuntansi menunjukkan hubungan positif yaitu terdapat pengaruh motivasi belajar terhadap hasil belajar pada mata pelajaran akuntansi.

Motivasi sangat erat hubungannya dengan aktualisasi diri, sehingga motivasi paling besar pengaruhnya pada kegiatan belajar mengajar siswa yang bertujuan untuk mencapai pemahaman siswa. Apabila tidak ada motivasi belajar dalam diri siswa, maka akan menimbulkan rasa malas untuk belajar baik dalam mengikuti proses belajar mengajar maupun mengerjakan tugas-tugas dari guru.

Dari hasil penjelasan di atas dapat diketahui bahwa ada kecenderungan siswa yang mempunyai motivasi belajar tinggi akan mempunyai minat dan semangat yang tinggi dalam belajar, sehingga siswa yang mempunyai motivasi belajar tinggi akan dapat belajar dengan senang dan sukarela, sebaliknya siswa yang tingkat motivasi belajarnya rendah akan mempunyai minat dan semangat yag rendah dalam belajar, dan malas untuk mengikuti proses pembelajaran.

Demikian pula dalam proses pembelajaran ekonomi, siswa yang mempunyai motivasi belajar yang tinggi akan mengikuti proses pembelajaran dengan hati yang senang, bersungguh-sungguh dalam memperhatikan pelajaran, dan dengan sukarela mengerjakan semua tugas yang diberikan oleh guru. Dengan berbekal semangat dan kesenangan hati tersebut, maka akan berdampak pada pemahaman ekonomi. Sebaliknya siswa yang memiliki motivasi belajar rendah akan mempunyai minat dan semangat yang rendah dalam belajar. Mereka akan cenderung kurang memperhatikan pelajaran, dan malas untuk mengerjakan tugas yang diberikan oleh guru, sehingga pemahaman mata pelajaran ekonomi yang dicapai juga rendah.

Siswa yang memiliki motovasi belajar yang baik, akan menghasilkan siswa dengan pemahaman yang baik pula pada mata pelajaran ekonomi. Motivasi belajar siswa berpengaruh signifikan terhadap pemahaman ekonomi siswa kelas XI IPS SMAN 1 Gondang, Nganjuk didukung oleh temuan pada variabel motivasi belajar dalam penelitian ini lebih dominan didukung oleh indikator Ulet menghadapi kesulitan. Hal ini dapat ditunjukkan oleh keadaan yang ada di lapangan apabila nilai tes ekonomi yang lalu kurang baik maka pada tes yang akan datang responden berusaha mendapatkan nilai yang lebih baik dari tes yang 
lalu. Ketika responden mendapat nilai ulangan baik, maka responden akan tetap belajar pada ulangan ekonomi selanjutnya. Selain itu responden tejun dan ulet dapat ditunjukkan dengan sikap selalu ingin memecahkan soal-soal.

Dari hasil analisis data, telah terbukti bahwa ada pengaruh yang signifikan antara motivasi belajar siswa terhadap pemahaman ekonomi. Dengan demikian dapat dikatakan semakin tinggi motivasi belajar yang dimiliki oleh siswa semakin tinggi pula pemahaman ekonomi yang dicapai. Hal ini sesuai dengan teori dan penelitian yang telah dilakukan sebelumnya. Adanya pengaruh dalam penelitian ini dapat disebabkan oleh dorongan yang diciptakan oleh guru dalam proses kegiatan belajar mengajar melalui pemberian tugas baik secara individu maupun kelompok, kuis, adanya penghargaan dalam belajar, serta danya kegiatan belajar yang menarik. Hasil temuan tersebut menunjukkan bahwa motivasi belajar siswa dalam kegiatan belajar di kelas memberikan sumbangan positif terhadap pemahaman ekonomi siswa.

\section{Pengaruh Gaya Belajar terhadap Pemahaman Ekonomi Siswa Kelas XI IPS di SMA Negeri 1 Gondang, Nganjuk}

Dalam penelitian ini diperoleh hasil bahwa gaya belajar (X3) secara parsial berpengaruh signifikan terhadap pemahaman ekonomi (Y). hal ini di dasarkan pada hasil uji t yaitu nilai t hitungnya sebesar 3,894 dan tingkat signifikansinya kurang dari 5\% yaitu 0,000. Hal ini menunjukkan bahwa gaya belajar siswa akan berpengaruh terhadap pemahaman ekonomi siswa kelas XI IPS SMA Negeri 1 Gondang, Ngnajuk. Adapun pengaruh gaya belajar (X3) terhadap pemahaman ekonomi adalah $4,08 \%$.

Deporter dan Hernacki (2010) Pemahaman tentang gaya belajar diharapkan dapat menentukan langkah-langkah supaya belajar lebih cepat dan mudah sesuai dengan kondisi masing-masing. Menurut Kolb (dalam Iriani, 2013) menyatakan keanekaragaman gaya belajar siswa perlu diketahui pada awal permulaannya diterima pada suatu lembaga pendidikan yang akan ia jalani. Hal ini akan memudahkan bagi pembelajar untuk belajar maupun pembelajar untuk mengajar dalam proses pembelajaran. Pembelajar akan dapat belajar dengan baik dan hasil belajarnya baik, apabila ia mengerti gaya belajarnya. Hal tersebut memudahkan pembelajar dapat menerapkan pembelajaran dengan mudah dan tepat.

Hal ini sesuai dengan penelitian sebelumnya yang digunakan sebagai rujukan oleh peneliti. Penelitian yang dilakukan oleh Mousavi, Renae dkk (1995) dengan judul Reducing Cognitive Load by Mixing Auditory and Visual Presentation Modes. Hasil ini menyebutkan bahwa penggunaan sebagian pendengaran dan sebagian visual presentasi untuk geometri contoh bekerja. Logikanya didasarkan pada efek split-perhatian dan efek presentasi modalitas pada memori kerja. Jadi kombinasi gaya belajar auditori dengan visual berpengaruh signifikan terhadap hasil belajar.

Hasrul (2009) dalam penelitian tentang pemahaman gaya belajar menyatakan bahwa untuk mencapai tujuan dalam pembelajaran perlu diketahui gaya belajar yang dimiliki oleh siswa karena hal ini akan mempermudah dalam proses pembelajaran di kelas. Karena gaya belajar disini merupakan cara yang cenderung dipilih seseorang untuk menerima informasi.

Penelitian lain yang sejenis oleh Ataturk (2011) dengan judul The Investigation of the learning styles of university students. Menurut hasil penelitian, terlihat bahwa sekitar setengah dari para siswa belajar secara visual. 
Dengan mengamati pengaruh jenis kelamin pada gaya belajar siswa, ditemukan bahwa, dalam pembelajaran visual, perempuan memiliki rata-rata lebih tinggi daripada anak laki-laki jelas dalam hal statistik. Selain itu, ia juga mencatat bahwa, baik departemen siswa maupun efek umum dari jenis kelamin maupun departemen tidak mempengaruhi gaya belajar. Gaya belajar mempunyai pengaruh terhadap tingkat pemahaman mahasiswa di universitas.

Penelitian oleh Gilakjani, Abbas dkk (2012), yang berjudul visual, auditory, kinaesthetic learning style and their impact on english language teaching, hasil penelitian menunjukkan bahwa terdapat tiga modalitas belajar yaitu secara visual, auditorial, dan kinestetik. Penelitian ini menganalisis gaya belajar di salah satu sekolah yang ada di Iran. Dan hasil penelitian menunjukkan bahwa pembelajaran bahasa inggris di salah satu sekolah di Iran lebih dominan dengan gaya belajar secara visual.

Penelitian lain yang sejenis dengan penelitian ini adalah penelitian oleh Nurtilawati dkk dengan judul pengaruh gaya belajar dan motivasi belajar terhadap hasil belajar siswa pada mata pelajaran ekonomi kelas X di SMAN 8 pontianak. Hasil analisis regresi menunjukkan variabel gaya belajar mempengaruhi variabel hasil belajar sebesar 24\%. Penelitian lain yang mendukung oleh Iriani, Dewi. (2013) yang berjudul Identifikasi Gaya Belajar dan Pengaruhnya terhadap Hasil Belajar siswa. Hasil dari penelitian ini diperoleh pengaruh yang signifikan gaya belajar terhadap hasil belajar matematika siswa kelas VIII SMPN 2 Kerinci. Besar pengaruh gaya belajar terhadap hasil belajar sebesar $18,85 \%$.

Penelitian lain yang mendukung penelitian ini adalah penelitian yang dilakukan oleh Iriani (2013), dengan judul Indentifikasi gaya belajar dan pengaruhnya terhadap hasil belajar siswa, hasil penelitian menunjukkan bahwa terdapat pengaruh yang signifikan gaya belajar terhadap hasil belajar.

Penelitian yang berbanding terbalik dan tidak mendukung penelitian ini adalah penelitian oleh Lilik (2012), judul penelitian yaitu pengaruh gaya belajar motivasi, dan pemahaman akuntansi terhadap indeks prestasi mahasiswa akuntansi. Dalam penelitian ini menyebutkan bahwa gaya belajar tidak mempunyai pengaruh yang signifikan terhadap indeks prestasi. jadi gaya belajar, motivasi dan pemahaman akuntansi tidak berpengaruh secara signifikan terhadap indeks prestasi.

Siswa yang mengetahui gaya belajarnya, akan menghasilkan siswa dengan pemahaman yang baik pula pada mata pelajaran ekonomi. Gaya belajar siswa berpengaruh signifikan terhadap pemahaman ekonomi siswa kelas XI IPS SMAN 1 Gondang, Nganjuk didukung oleh temuan pada variabel gaya belajar dalam penelitian ini lebih dominan didukung oleh indikator gaya belajar visual. Terlihat dari cara siswa dalam menerima pembelajaran di kelas, cenderung menggunakan penglihatan mereka. Misalnya responden lebih memahami penjelasan dari materi ekonomi dengan cara yang mudah di ingat seperti membuat gambar, mind mapping, bagan-bagan dll. Hasil temuan tersebut menunjukkan bahwa gaya belajar responden adalah cenderung menggunakan gaya belajar secara visual. Dengan diketahuinya gaya belajar siswa dalam kegiatan belajar di kelas memberikan sumbangan positif terhadap pemahaman ekonomi siswa.

4. Pengaruh Kompetensi Profesional Guru, Motivasi Belajar dan Gaya Belajar terhadap Pemahaman Ekonomi Siswa Kelas XI IPS di SMA Negeri 1 Gondang, Nganjuk 
Berdasarkan hasil uji secara simultan menunjukkan bahwa kompetensi profesional guru, motivasi belajar dan gaya belajar berpengaruh signifikan terhadap pemahaman ekonomi siswa. Hasil penelitian ini terlihat dari $\mathrm{F}_{\text {hitung }}$ sebesar 95,377 dengan nilai signifikansi sebesar 0,000 kurang dari 5\% sehingga dapat disimpulkan bahwa kompetensi profesional guru (X1), motivasi belajar (X2), dan gaya belajar (X3) secara simultan berpengaruh signifikan terhadap pemahaman ekonomi (Y). besarnya pengaruh kompetensi profesional guru (X1), motivasi belajar (X2), dan gaya belajar (X3) secara simultan terhadap pemahaman ekonomi (Y) sebesar 77,3\% sedangkan 22,7\% dipengaruhi oleh faktor-faktor lain, selain variabel kompetensi profesional guru, motivasi belajar dan gaya belajar.

Hal ini sesuai dengan teori yang dikemukakan oleh Djamarah (2011) yakni bahwa guru yang bermutu niscaya mampu melaksanakan pendidikan, pengajaran, dan pelatihan yang efektif dan efisien. Guru yang profesional diyakini mampu memotivasi siswa untuk mengoptimalkan potensinya dalam kerangka pencapaian standar pendidikan yang ditetapkan. Deporter dan Hernacki (2010) mengemukakan tentang gaya belajar, Pemahaman tentang gaya belajar diharapkan dapat menentukan langkah-langkah supaya belajar lebih cepat dan mudah sesuai dengan kondisi masing-masing.

Hal ini juga sesuai dengan penelitian sebelumnya yang digunakan sebagai rujukan oleh peneliti. Penelitian yang dilakukan oleh Rejeki (2011) dengan judul pengaruh kondisi ekonomi keluarga, motivasi belajar, dan gaya belajar terhadap hasil belajar siswa. Hasil penelitian ini mengemukakan bahwa terdapat pengaruh langsung positif motivasi belajar terhadap hasil belajar, terdapat pengaruh langsung positif gaya belajar terhadap hasil belajar. Secara simultan terdapat pengaruh kondisi ekonomi keluarga, motivasi belajar, dan gaya belajar terhadap hasil belajar siswa.

Selanjutnya penelitian oleh Sulistyowati, dkk (2012), dengan judul Pengaruh motivasi belajar dan kompetensi profesional guru terhadap prestasi belajar mata pelajaran ips ekonomi. Hasil penelitian menyatakan bahwa secara simultan ada pengaruh yang signifikan antara motivasi belajar dan kompetensi profesional guru terhadap prestasi belajar IPS ekonomi. Fakta yang ditemukan dilapangan menunjukkan bahwa kompetensi profesionalisme guru yang semakin tinggi dalam pembelajaran, semakin tinggi motivasi belajar siswa dan mengetahui gaya belajar, maka akan semakin tinggi pula pemahaman ekonomi siswa. Hal ini juga sesuai dengan jabatan guru sebagai tenaga profesional dengan tugas utama mendidik, mengajar, membimbing, mengarahkan, melatih dan mengevaluasi dari kegiatan belajar.

Dari penelitian tentang kompetensi profesional guru, motivasi belajar dan gaya belajar berpengaruh terhadap pemahaman ekonomi di atas dapat dijadikan landasan bahwa variabel kompetensi guru, motivasi belajar dan gaya belajar berpengaruh secara signifikan terhadap pemahaman ekonomi.

Kompetensi profesional guru, motivasi belajar, dan Gaya belajar siswa berpengaruh signifikan terhadap pemahaman ekonomi siswa kelas XI IPS SMAN 1 Gondang, Nganjuk didukung oleh temuan pada variabel motivasi belajar. Dari ketiga variabel tersebut yang berpengaruh paling dominan adalah motivasi belajar. Hasil temuan tersebut menunjukkan bahwa motivasi belajar siswa memberikan sumbangan paling besar daripada variabel yang lain yaitu kompetensi profesional guru dan motivasi belajar terhadap pemahaman ekonomi. 


\section{KESIMPULAN}

Berdasarkan pembahasan dan hasil analisis data yang dilakukan dalam penelitian ini dapat disimpulkan sebgai berikut: (1) Ada pengaruh signifikan Kompetensi profesional guru terhadap pemahaman ekonomi siswa kelas XI IPS di SMA Negeri 1 Gondang, Nganjuk. Hal ini berarti semakin tinggi kompetensi profesional guru maka semakin tinggi pula pemahaman ekonomi siswa; (2) Ada pengaruh signifikan motivasi belajar siswa terhadap pemahaman ekonomi siswa kelas XI IPS di SMA Negeri 1 Gondang, Nganjuk. Hal ini berarti semakin tinggi motivasi belajar siswa maka semakin tinggi pula pemahaman ekonomi siswa tersebut; (3) Ada pengaruh signifikan gaya belajar terhadap pemahaman ekonomi siswa kelas XI IPS di SMA Negeri 1 Gondang, Nganjuk. Hal ini berarti gaya belajar yang dimiliki siswa akan berpengaruh terhadap pemahaman ekonomi siswa; (4) Ada pengaruh signifikan kompetensi profesional guru, motivasi belajar dan gaya belajar secara bersama-sama terhadap pemahaman ekonomi siswa kelas XI IPS SMA Negeri 1 Gondang, Nganjuk. Hal ini berarti semakin tinggi kompetensi profesional guru, motivasi belajar dan gaya belajar maka semakin tinggi pemahaman ekonomi siswa kelas XI IPS SMA Negeri 1 Gondang, Nganjuk.

\section{DAFTAR RUJUKAN}

Ataturk (2011), penelitiannya yaitu The Investigation of the learning styles of university. The Online Journal of New Horizons in Education Volume 3, Issue 1. Diakses pada tanggal 28 Maret 2014.

Departemen Pendidikan Nasional. 2005. Undang-Undang Republik Indonesia Nomor 14 Tahun 2005, tentang Guru dan Dosen.

Djamarah, S.B. 2011. Psikologi belajar. Jakarta: PT Rineka Cipta.

Ghamari, Mohammad. 2011. "The Relationship of Internal Motivation Components and Academic Achievment among High School Student". International Journal of Human Resource Studies. ISSN Vol. 1 No. 2. 2011. Diakses pada tanggal 14 Oktober 2013

Hamdu, Ghullam, Lisa Agustina. 2011. "pengaruh motivasi belajar siswa dengan prestasi belajar IPA Di Sekolah Dasar". Jurnal Penelitian Pendidikan Vol. 12 No. 1 April 2011. Diakses pada tanggal 20 Oktober 2013

Gintings, Abdorrakhman. 2010. Esensi Praktis Belajar dan Pembelajaran.. Bandung : Humaniora.

Hamalik, Oemar. 2001. Psroses Belajar dan Mengajar. Jakarta: Bumi Aksara.

Hamalik, Oemar. 2004. Psikologi Belajar dan Mengajar. Bandung: Sinar Baru.

Hasrul. 2009." Pemahaman tentang gaya belajar". Jurnal MEDTEK, Volume 1, Nomor 2, Oktober 2009. Diakses pada tanggal 10 Oktober 2013

Iriani, Dewi dan Mutia, Leny. 2013." Identifikasi Gaya Belajar dan Pengaruhnya terhadap Hasil Belajar siswa pada Materi Kubus dan Balok di Kelas VIII SMPN 2 Kerinci". Prosiding Semirata FMIPA Universitas Lampung. Diakses pada tanggal 05 Oktober 2013.

Joy, Telu Hamilton Ekeke. 2012. Conceptual framework of teacher's competence in relation to students' academic achievment.International journal of 
Networks and systems. Volume 2, No 3, April-May 2013. diakses pada tanggal 14 Desember 2013.

Kulshrestha. 2013. "Teachers Training and Profesional Competence". ISSN. Vol. 2 Isuue 4. March 2013

Majid. Abdul, 2011. Perencanaan Pembelajaran Mengembangkan Standar Kompetensi Guru, Bandung : PT Remaja Rosdakarya.

Mousavi, Renae dkk. 1995, Reducing Cognitive Load by Mixing Auditory and Visual Presentation Modes. ". Journal of Educational Psychology Vol. 87, No. 2, 319-334 Diakses pada tanggal 13 April 2014

Nasution, M.A. 2008. Berbagai Pendekatan dalam Proses Belajar dan Mengajar. Jakarta: Bumi Aksara.

Purwanto, Ngalim, M. 2000. Pendidikan Teoritis dan Praktis, Bandung : PT Remaja Rosdakarya.

Sardiman, A.M. 2011. Interaksi dan Motivasi Belajar Mengajar. Jakarta: PT. Raja Grafindo

Sugiyono. 2010. Metode Penelitian Pendidikan :Pendekatan kuantitatif, kualitatif, dan $R \&$ D. Bandung : Alfabeta

Suprijono, Agus. 2011. Cooperative Learning Teori \& Aplikasi Paikem. Yogyakarta: Pustaka Pelajar.

Rejeki, Sri. 2011. "pengaruh kondisi ekonomi keluarga, motivasi belajar, dan gaya belajar terhadap hasil belajar siswa". Diakses pada tanggal 05 Oktober 2013

Sulistyowati, Yunik dkk. 2012, Pengaruh motivasi belajar dan kompetensi profesional guru terhadap prestasi belajar mata pelajaran ips ekonomi siswa kelas vii smp negeri 3 magelang tahun pelajaran 2011/2012. Economic Education Analysis Journal. Diakses pada tanggal 28 Maret 2014.

Trianto. 2010. Mendesain Model Pembelajaran Inovatif-Progresif. Jakarta : PT. Kencana.

Upami, Lilik. 2012, "pengaruh gaya belajar motivasi, dan pemahaman akuntansi terhadap indeks prestasi mahasiswa akuntansi". Jurnal Pendidikan 2012. Diakses pada tanggal 30 Maret 2014.

Usman Uzer.M. 2011. Menjadi Guru Profesional. Bandung : Remaja Rosdakarya. 